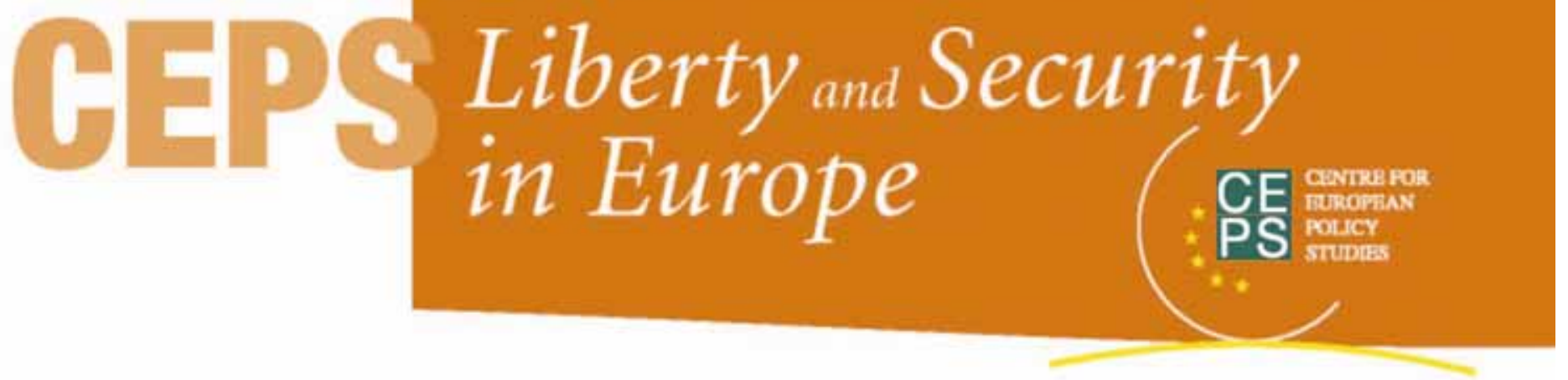

\title{
State Protection of the Czech Roma and the Canadian Refugee System
}

\author{
Marina Caparini
}

November 2010

\begin{abstract}
This paper examines state protection as applied to the Roma minority group in the Czech Republic and the link to Roma refugee claimants in Canada. The paper traces measures implemented by the Czech national authorities to improve the situation of the Roma, but also continuing problems of discrimination and violence by state and non-state actors. It also describes the often weak implementation and enforcement of anti-discrimination measures by state officials and the judiciary, among which are the failure to properly investigate and hold accountable public officials, including police officers, accused of misconduct towards members of the Roma minority. The paper then examines the Canadian governmental response to the 2008-09 influx of Czech Roma refugee claimants. It argues that Canada's response reflected broader trends among receiving states, particularly the effort to reinforce state sovereignty and territorial control, and in concert with efforts to exert greater political influence over the refugee determination process, the response resulted in the weakening of Canada's obligations under the international refugee regime.
\end{abstract}

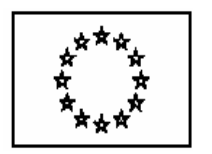

This work was prepared as part of a project on Migration and Asylum in Europe and EUCanada Relations, funded by the European Commission, Directorate-General for External Relations, Relations with the US and Canada. The project studies EU-Canada cooperation on migration and asylum policies. It aims at providing a better understanding of the conceptual, political, sociological and legal elements and dilemmas characterising the development of common European public responses to these issues, and their implications for the relationship between liberty and security in EU-Canada relations.

The CEPS 'Liberty and Security in Europe' publication series offers the views and critical reflections of CEPS researchers and external collaborators on key policy discussions surrounding the construction of the EU's Area of Freedom, Security and Justice. The series encompasses policy-oriented and interdisciplinary academic studies and commentary about the internal and external implications of $J$ ustice and Home Affairs policies inside Europe and elsewhere throughout the world.

Unless otherwise indicated, the views expressed are attributable only to the author in a personal capacity and not to any institution with which she is associated. This publication may be reproduced or transmitted in any form for non-profit purposes only and on the condition that the source is fully acknowledged. 


\section{CONTENTS}

1. Czech state protection vis-à-vis the Roma minority ......................................................... 3

1.1 EU pressure and Czech initiatives to improve the situation of the Roma ....................5 5

1.2 Post-accession initiatives on the situation of the Roma .............................................. 9

1.3 Current situation of the Roma minority ……........................................................... 11

2. The response of the Canadian government to Roma asylum claims, 1997-2010 ............... 14

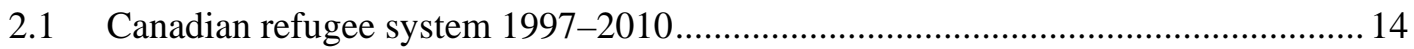

2.2 Bill C-11: Reforming the Canadian refugee system ................................................. 18

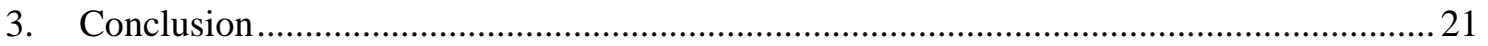

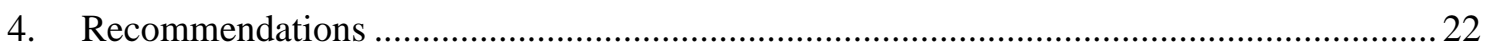

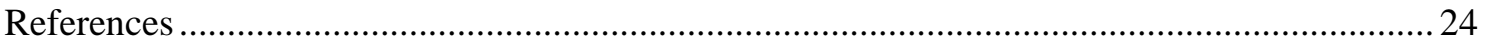




\section{State Protection of the Czech Roma and the Canadian Refugee System Marina Caparini*}

CEPS Paper in Liberty and Security in Europe, November 2010

$\mathrm{I}$ n October 2007 Canadian authorities determined that Czech nationals would no longer require a visa to enter Canada. The visa requirement had initially been imposed in 1997 to stem an influx of Czech citizens, mostly members of the Roma ethnic minority, who applied for refugee status upon entering Canada. Shortly after the visa requirement was removed in 2007, increasing numbers of Roma again began to arrive in Canada and file refugee claims. Within the first six months of 2009 more than 1,700 Czech Roma had applied for asylum. Critics in both the Czech Republic and Canada maintained that the Roma refugee applicants were primarily "economic migrants" and were merely using Canada's liberal refugee system as a means of "jumping the queue" or entering Canada "by the backdoor". ${ }^{1}$ Canada's immigration minister concurred, stating that "it is hard to believe that the Czech Republic is an island of persecution in Europe" ${ }^{2}$ and referred to "bogus refugee claims” by Czech Roma. ${ }^{3}$ In July 2009 Canadian authorities reimposed the visa requirement.

Yet the claims of persecution by Czech Roma are not so easily dismissed. Despite various Czech legislative and policy initiatives to improve the situation of the Roma, domestic and international human rights organisations have documented systemic discrimination and severe socio-economic marginalisation, tolerance of public hate speech against the Roma, anti-Roma demonstrations, and attacks on Roma individuals and communities by members of far-right groups. Discrimination at the hands of the Czech state authorities, notably the police and judicial system, further buttress allegations that the Czech state has failed to protect the fundamental rights of Roma citizens.

This paper examines the issue of Czech Roma refugee claimants and the Canadian governmental response as reflecting the interplay between two broader trends that are affecting how contemporary states govern people and territory: on the one hand, the diffusion and active promotion of human rights norms, and on the other hand the increasing efforts by Western receiving states to assert control over migration flows. Explaining the relevance of this issue requires looking beyond the strains provoked in Canada's diplomatic relations with the Czech Republic and with the EU more broadly, and requires examining how these co-existing dynamics of inclusion and exclusion are affecting the refugee regime through the core notion of state protection.

Upon becoming a candidate for EU membership, the Czech Republic came under increasing pressure to protect the human rights of the Roma and improve their condition within society. Through the political conditions of the Copenhagen criteria on democratic governance, rule of law, respect for human rights, and respect for and protection of minorities, the EU linked

\footnotetext{
* Senior Research Fellow, Norwegian Institute of International Affairs (NUPI). The author wishes to express her gratitude to Sergio Carrera for his valuable comments.

${ }^{1}$ Ian Willoughby, “Why did so many Czech Roma apply for asylum in Canada?”, Radio Prague (online), 28 July 2009.

${ }^{2}$ Peter O’Neil, “Canada getting flooded with Czech refugee claims”, CanWest News, 15 April 2009.

${ }^{3}$ Nicholas Köhler, “A crackdown on queue-jumpers”, Maclean’s, Vol. 122, Nos. 29/30, 3 August 2009, pp. 19-20.
} 


\section{2 | MARINA CAPARINI}

progress in those areas to candidates' prospects for receiving an invitation to join the EU. Drawing in part on information provided by various human rights organisations and agencies, including the Council of Europe and Organisation for Security and Cooperation in Europe (OSCE), the situation of the Roma became a prominent theme in monitoring the political conditions in the lead-up to accession. This prompted the Czech central government to implement various laws and policies to address persistent systemic discrimination against the Roma, although the effectiveness of these measures remains in question, especially at the local level.

At the same time, Canada's reaction to the 2008-09 wave of Czech Roma refugee claimants reflected the wider tendencies of developed 'receiving' states in the international refugee regime to counter a supposed 'flood' of asylum seekers by enacting measures to deter or dissuade potential refugees from reaching their borders, despite the fact that over $80 \%$ of the world's refugees remain in developing countries. ${ }^{4}$ Over the past decade the international refugee regime has come under sustained pressure as a result of globalisation, with small but increasing flows of refugees to wealthy Western countries spurring the efforts of those receiving states to loosen constraints imposed by international law on executive action in controlling the access of migrants to their territory, and thereby reinforcing territorial sovereignty. ${ }^{5}$ The imposition of visas is one of several 'non-entrée' practices being implemented by Canada and other industrialised receiving states to interdict potential asylum claimants before entering their territory, thus denying potential claimants access to their refugee determination procedures. Furthermore, the exclusionary tendency has had domestic political implications through the efforts of the government of Prime Minister Stephen Harper to shape public perceptions about Canada's traditionally liberal asylum system. During the 2008-09 influx of Czech Roma, sceptical statements by the Canadian immigration minister about the legitimacy of Roma refugee claims and alleged abuse of the asylum system were perceived as political interference in Canada's ostensibly independent refugee determination process and an attempt to influence domestic expectations concerning Canada's international obligations to protect refugees.

Critical to understanding the issue of the Czech Roma refugee claimants is 'state protection' or the primary responsibility of a state under international law for protecting the fundamental rights of all individuals within its territory, including the rights to life and security. State signatories to the 1951 United Nations Convention Relating to the Status of Refugees and the 1967 Protocol (henceforth 'Convention') acknowledge the right of individuals to seek protection from another state when their state of origin is unable or unwilling to provide such protection. A refugee, according to the Convention, is defined by an individual's inability or unwillingness to return to his or her country of origin owing to a "well-founded fear of being persecuted" based on race, religion, nationality, membership in a particular social group or political opinion. ${ }^{6}$ The Convention also prohibits state parties from returning refugees (nonrefoulement) if doing so would likely threaten their lives or freedom, and obliges signatories to grant those refugees state protection.

This paper has a dual focus on the issue of state protection with regard to the Czech Roma, as it has been implemented by the (Czech) state of origin, and as the basis upon which the

\footnotetext{
${ }^{4}$ See Antonio Guterres, "World Refugee Day: 42 million uprooted people waiting to go home”, United Nations High Commissioner for Refugees, Geneva, 19 June 2009; see also statistical tables in US Committee for Refugees and Immigrants (USCRI), World Refugee Survey 2009, USCRI, Arlington, VA, 2009.

${ }^{5}$ Catherine Dauvergne, Making People Illegal: What Globalization Means for Migration and Law, Cambridge: Cambridge University Press, 2008, pp. 50-68.

${ }^{6}$ See Art. 1A(2), UN General Assembly, Convention Relating to the Status of Refugees, 28 July 1951, U.N.T.S. Vol. 189, p. 137.
} 
(Canadian) receiving state registers and adjudicates refugee claims. The paper first examines the situation of the Roma in the Czech Republic and how the Czech state has responded to international and domestic criticism about its capacity and willingness to protect the human rights of Roma citizens and residents. As an aspiring and eventually official member of the EU, the Czech Republic became subject to monitoring, technical assistance, and legal and political pressures to adopt more stringent human rights and minority protection guarantees. The paper explores some of the mechanisms by which state protection has been strengthened in the Czech Republic with respect to the Roma, and areas in which it has continued to lag, including in the socio-economic spheres and at local levels of administration. The paper then turns to the issue of state protection in Canada, specifically how Canada has approached the issue of state protection for Czech Roma refugee claimants, initially in relation to an earlier influx in 1997 and subsequently to the 2008-09 wave of applicants. It also explores the efforts by the government of Stephen Harper to implement reforms to the Canadian refugee system in the wake of the Czech Roma issue, in part through the discursive tactic of conflating refugees, including the Czech Roma refugee claimants, with 'illegal' (irregular) migrants. One result of the Canadian governmental response is an apparent loss of traction of the concept and legal obligation of state protection as a political value in the domestic public discourse about Canadian refugee policy. Finally, based on the Czech Roma case, the paper makes policy recommendations aimed at strengthening state protection practices by Canada, the Czech Republic and the EU.

\section{Czech state protection vis-à-vis the Roma minority}

Following the collapse of the Czechoslovak communist regime in late 1989, racially motivated attacks and discrimination by state and private actors against the Roma minority began to increase. While similar outbreaks of violence and discrimination against the Roma were witnessed across Eastern Europe in the early 1990s, the Czech Republic was distinguished by the deliberate effort of the new state to establish its resident Roma population as a group of noncitizens who were denied many social and legal rights. ${ }^{7}$ Through the Citizenship Law of 1993, which came into being after the dissolution of the Czechoslovak Federation at the end of 1992, between 10,000 and 20,000 former Czechoslovak citizens of Roma ethnicity were denied Czech citizenship. ${ }^{8}$ The conditions set for Czech citizenship included proof of permanent residency in the Czech Republic on its creation on 1 January 1993; the status of the housing they occupied (temporary accommodation, which many Roma inhabited, did not qualify); a clean criminal record for the past five years regardless of the nature of the crime (Roma had a disproportionately high incidence of records for pick-pocketing or petty theft relative to the nonRoma population, which was reflective of their high levels of unemployment and poor socioeconomic conditions); ${ }^{9}$ and fluency in the Czech language (many Roma were illiterate in Czech). The Citizenship Law denied many Roma Czech citizenship, even if they had spent most or all of their lives in Czech lands or had effective ties through work or family. As a result of sustained international criticism for not conforming to European or international human rights law, the Czech law was amended several times but significant numbers of Roma individuals remained unable to legalise their status in the Czech Republic.

\footnotetext{
${ }^{7}$ Beata Struharova, "Disparate impact: Removing Roma from the Czech Republic”, European Roma Rights Centre, Budapest, 7 July 2004 (http://www.errc.org/cikk.php?cikk=549).

${ }^{8}$ Helen O’Nions, Minority Rights Protection in International Law: The Roma of Europe, Aldershot: Ashgate, 2007, p. 122.

${ }^{9}$ Robin H.E. Shepherd, Czechoslovakia: The Velvet Revolution and Beyond, Houndmills, Basingstoke and New York: Palgrave, 2000, p. 118.
} 
Throughout the 1990s, domestic and international human rights organisations documented police and public violence aimed at members of the Roma minority and systematic discrimination in education, housing, the labour market, health care and other municipal services. ${ }^{10}$ Czech authorities, especially the local police, were criticised by international human rights observers for failing to adequately protect the Roma from racist attacks, for engaging in discriminatory practices such as ethnic profiling, and for regularly using excessive force towards visible minorities, especially the Roma, while failing to hold officers accountable for such misconduct. ${ }^{11}$ The Czech criminal justice system was also criticised for denying Roma equal treatment before the law and for regularly failing to adequately investigate violence against the Roma, take appropriate measures including criminal prosecution and punish perpetrators of racist violence to the full extent of the law. Also common was the diminution of racist attacks as interpersonal disputes, and when evidence of guilt was established, the handing down of light sentences for racist violence. ${ }^{12}$

Socio-economic marginalisation also continued: making up a high proportion of unskilled labourers and facing discrimination in the workplace, the Roma were markedly affected by the disruption caused by the economic transformation, and Roma unemployment in some regions reached 90\%. ${ }^{13}$ Furthermore, anti-Roma sentiment was more pronounced in Czech public opinion compared with other post-communist states. According to one public opinion poll taken in the 1990s, 91\% of Czechs disliked the Roma, compared with 79\% in Hungary and 68\% in Romania. ${ }^{14}$ Until 1997, however, the Czech government largely ignored or denied the existence of widespread discrimination and violence against the Roma, framing the problem as one resulting fundamentally from social and cultural differences between the Roma and the Czech majority, rather than from the failure of the state to enforce human rights standards for all citizens. ${ }^{15}$ The government of Prime Minister Vaclav Klaus was criticised for adopting or tacitly endorsing repressive and exclusionary measures towards the Roma, ostensibly to maintain public security and public order in the face of alleged Roma criminality and anti-social behaviour. ${ }^{16}$

Yet by 1997 the Czech government's approach towards the Roma minority began to show some change. One specific source of pressure on the Czech government was the high-profile exodus over the summer of 1997 of Czech Roma who applied for refugee status in the UK and Canada (discussed below). The surge in asylum seekers from a country widely viewed as a leader in post-communist democratisation and a front-runner for eventual EU membership attracted international attention and caused embarrassment for Prague. By October 1997, more than

\footnotetext{
${ }^{10}$ For examples, see the country reports on the Czech Republic and Roma-focused thematic reports from Human Rights Watch, Amnesty International and the European Roma Rights Centre. See also the Organisation for Security and Cooperation in Europe (OSCE), Report on the situation of Roma and Sinti in the OSCE area, OSCE, Vienna, 2000.

${ }^{11}$ International Federation for Human Rights (FIDH) and the League of Human Rights in the Czech Republic (LLP), Czech Republic: Impunity of Racially Motivated Attacks and Police Violence Still Prevails, FIDH and LLP, Paris and Prague, 18 November 2002 (http://www.fidh.org/IMG/pdf/cz1811a.pdf).

${ }^{12}$ Human Rights Watch, Roma in the Czech Republic: Foreigners in their Own Land, Vol. 8, No. 11 (D), Human Rights Watch, New York, NY, June 1996, pp. $2,5$.

${ }^{13}$ See "Roma asylum seekers undaunted”, Radio Prague (online), 2 August 1999.

${ }^{14}$ Safia Swimelar, "The Making of Minority Rights Norms in the Context of EU Enlargement: The Czech Republic and the Roma”, International Journal of Human Rights, Vol. 12, No. 4, 2008, p. 510, 31n.

${ }^{15}$ Ibid., p. 512.

${ }^{16}$ Eva Sobotka, "Czech Republic: Exceptionality and conditionality at work”, in Bernd Rechel (ed.), Minority Rights in Central and Eastern Europe, London and New York: Routledge, 2009, p. 94.
} 
1,300 Czech Roma had applied for asylum that year in Canada alone, leading the Canadian government to reinstate a visa regime for all Czech nationals, effectively bringing an end to the arrival and refugee claims of Czech Roma in Canada. ${ }^{17}$

\subsection{EU pressure and Czech initiatives to improve the situation of the Roma}

Another developing source of pressure was the EU. As human rights organisations drew attention to the discrimination faced by the Roma, who were migrating and claiming asylum in key partner countries (such as Canada) and in EU member states (such as the UK), it became increasingly evident that several of the applicant states had unresolved human rights problems. ${ }^{18}$ In its Agenda 2000 document of 1997, the European Commission flagged the treatment of the Roma minority as a problem for several of the applicant countries. ${ }^{19}$ Minority protection henceforth became an area of focus of the EU's monitoring of reforms in candidate states, linked specifically to the compliance of candidate states with the political conditions of the Copenhagen criteria.

The European Commission's 1997 Opinion on the Czech Republic's application for membership of the EU found that the Roma "are the target of numerous forms of discrimination in their daily lives and suffer particular violence from skinheads, without adequate protection from the authorities or the police". ${ }^{20}$ The Opinion also noted the discriminatory effects of the 1993 Czech citizenship law. ${ }^{21}$ In October 1997 the Czech government began to adjust its approach towards the Roma and initiated debate on a series of proposals for greater Roma integration. In the Report on the Situation of the Romani Community in the Czech Republic submitted by minister without portfolio Pavel Bratinka, proposed measures included requiring the minister of interior to monitor racist criminal offences and report regularly to the government on the prosecution of these crimes. Other measures included initiatives to recruit more individuals from Roma communities to train and work as police officers. ${ }^{22}$ Further pressure to address the Roma issue was exerted in March 1998, when the European Parliament warned that it would not approve the accession criteria for EU associate members unless integration of the Roma was given higher priority by designating it a short-term objective, thus requiring immediate action, rather than a medium-term one. ${ }^{23}$ The message that this was a matter of concern in Brussels and Strasbourg was evidently understood by Prague, when Prime Minister Milos Zeman acknowledged in 1999 that future Czech accession to the EU was most put at risk by the situation of the Roma. ${ }^{24}$

${ }^{17}$ Gerald Kernerman, “Refugee Interdiction Before Heaven’s Gate”, Government \& Opposition, Vol. 43, No. 2, 2008, pp. 237-238.

${ }^{18}$ Peter Vermeersch, "EU Enlargement and Minority Rights Policies in Central Europe: Explaining Policy Shifts in the Czech Republic, Hungary and Poland”, Journal on Ethnopolitics and Minority Issues in Europe, No. 1, 2003, p. 10.

${ }^{19}$ European Commission, Agenda 2000 - Commission Opinion on the Czech Republic's Application for Membership of the European Union, DOC/97/17, Brussels, 15 July 1997, p. 16 (henceforth '1997 Opinion').

${ }^{20}$ Ibid., p. 16.

${ }^{21}$ Ibid., p. 14.

${ }^{22}$ Pavel Bratinka, Report on the Situation of the Romani Community in the Czech Republic and Governmental Measures Assisting its Integration into Society, Prague, 29 October 2007.

${ }^{23}$ O’Nions (2007), op. cit., p. 128.

${ }^{24}$ Rick Fawn, “Czech Attitudes Towards the Roma: 'Expecting more of Havel's country?'”, Europe-Asia Studies, Vol. 53, No. 8, 2001, p. 1193. 
Still, despite the various Czech policy and legislative initiatives introduced since 1997, the Roma minority continued to be impoverished, marginalised and the subject of systemic discrimination by state and private actors. Successive annual monitoring reports by the European Commission criticised the discriminatory behaviour and abusive actions of police towards Roma individuals. In 2002, while noting that much progress had been made by the Czech Republic regarding treatment of the Roma, the Commission noted that improvement was needed in combating racially motivated violence, "including where it would be committed by the police" and that there remained room for improvement by law enforcement officials, specifically with regard to the Roma. ${ }^{25}$ Related to this was the continuing problem of inadequate systems for police accountability, allowing impunity for misconduct by police officers to continue in practice. The European Commission noted the priority need for the Czech Republic to establish a system for dealing with police misconduct, including through the establishment of a police code of ethics. ${ }^{26}$

Reports by human rights organisations and relevant bodies of the OSCE and the Council of Europe, such as the European Commission against Racism and Intolerance (ECRI), also documented discriminatory police behaviour towards Roma. For example, in a report published in 2000, the ECRI noted "evidence of differential treatment of members of minority groups, especially Roma/Gypsies, on the part of some Czech national and municipal law enforcement officials", as well as "complaints about harassment and excessive use of force, deliberate prolonging of investigations, wrongful arrests and ill-treatment of detainees belong to this category of people". ${ }^{27}$ Furthermore, it found that the Czech law enforcement's response to racially motivated crime tended to be inadequate, with evidence that certain officers displayed racist attitudes and sympathies towards right-wing extremist groups. With regard to police accountability, the ECRI highlighted the reluctance of police investigators to identify problems of racism among fellow police officers and that the investigation process into police misconduct lacked transparency. The ECRI pointed to the need for impartial investigations of allegations of ill treatment by the police and misconduct towards members of minority groups and the need to eliminate police impunity in this respect. ${ }^{28}$

As noted in a 2002 report by the Council of Europe Advisory Committee monitoring the implementation of the Framework Convention for the Protection of Minorities, the treatment of Roma by Czech public authorities, especially the police, remained a matter of concern. Not only was racially motivated crime continuing, but also as the Czech government acknowledged, most such offences were unlikely to be reported to the police. This was attributed to the persisting lack of trust between the Roma minority and the police authorities, as well as negative attitudes held by the police, particularly at the local level, towards members of the Roma minority. ${ }^{29}$ The report recommended that the Czech government ensure that the work of the police be subject to constant monitoring, and "the existence of an effective system of appeals against action or inaction by the police, especially with regard to ethnically-motivated crimes". ${ }^{30}$ Although some training on human rights awareness for national police personnel had been implemented, efforts

\footnotetext{
${ }^{25}$ European Commission, Regular Report 2002, SEC(2002) 1402, Brussels, 2002, pp. 32-33.

${ }^{26}$ Ibid., p. 27.

${ }^{27}$ European Commission against Racism and Intolerance (ECRI), Second Report on the Czech Republic, adopted 18 June 1999, ECRI, Brussels, 2000, p. 4, para. 16.

${ }^{28}$ Ibid., p. 4, paras. 17 and 18.

${ }^{29}$ Council of Europe, Advisory Committee on the Framework Convention for the Protection of National Minorities, Opinion on the Czech Republic, adopted 6 April 2001, ACFC/INF/OP/I(2002)02, Strasbourg, 2001, paras. 39 and 40.

${ }^{30}$ Ibid., para. 40.
} 
to recruit national minorities into the police had proven inadequate. And while the Czech authorities had shown an improved record of investigating ethnically motivated crimes, the Advisory Committee maintained that these efforts were insufficient, and that the Czech police and justice system remained generally unwilling to adequately prevent, investigate and prosecute ethnically motivated crime. ${ }^{31}$ In short, the Czech police often failed to take Roma complaints of discrimination or ethnically motivated violence seriously, and Czech courts usually failed to vigorously prosecute those accused of ethnically motivated crimes. ${ }^{32}$

Although rights guarantees were enshrined in the Czech Charter of Fundamental Rights and Freedoms, this did not provide effective protection against racial discrimination as claimed by Vaclav Klaus and other senior politicians. ${ }^{33}$ Nor were anti-discrimination policies necessarily implemented or enforced effectively, notably by local governments, which often did not share the central government's concerns or priorities on this account. Despite the development in 2000 by the Czech government of a framework 'Concept on the Roma' in which ensuring the security of Roma was one of the main priorities, ${ }^{34}$ its implementation was criticised by nongovernmental actors as largely declaratory, superficial, not addressing root causes and having minimal impact. ${ }^{35}$ The Concept did not, for example, address discrimination in the criminal justice system among police, investigators, public prosecutors and judges. ${ }^{36}$ The Czech government viewed the training efforts, lectures and seminars that it had introduced for police in dealing with racially motivated crime as successful and as requiring no further measures. ${ }^{37}$ And while an increasing number of police were being trained and tasked with monitoring extremism in order to better address racially motivated violence against Roma, Czech and international non-governmental organisations (NGOs) on human rights noted that such violence nevertheless continued, and that police reporting, investigation and action to combat racially motivated crime needed to be improved. ${ }^{38}$ Moreover, attacks and excessive use of force against Roma perpetrated by members of the police continued, as did police impunity for such behaviour. ${ }^{39}$

The Czech national authorities attempted to respond to European Commission criticisms regarding police relations with minorities. The 2003 national strategy for police work with respect to national minorities set out improved training for police in human rights and diversity awareness, increased minority recruitment, and closer monitoring of attitudes of hostility, intolerance and racism among police. It also prescribed the finalisation of a code of conduct for law enforcement officers, drawing on existing law enforcement codes of conduct, and it specifically recommended the inclusion of a provision concerning police conduct in relation to national and ethnic minorities. ${ }^{40}$ Police oversight had been improved through the elaboration of an amendment to the Code of Criminal Procedure that took effect in 2002 and according to which offences committed by police officers would henceforth be investigated by prosecutors

\footnotetext{
${ }^{31}$ Ibid., para. 43.

${ }^{32}$ Melanie H. Ram, "Democratization through European Integration: The Case of Minority Rights in the Czech Republic and Romania”, Studies in Comparative and International Development, Vol. 38, No. 2, summer, 2003, p. 50.

${ }^{33}$ Struharova (2004), op. cit.

34 Czech Republic, Concept of Governmental Policy Towards Members of the Roma Community Supporting their Integration into Society, adopted 14 June 2000, Prague.

${ }^{35}$ Open Society Institute (OSI), Minority Protection in the Czech Republic, OSI, 2002, p. 126.

${ }^{36}$ Ibid., p. 129.

${ }^{37}$ Ibid., pp. 169-170.

${ }^{38}$ ECRI (2000), op. cit., p. 4, para. 20.

${ }^{39}$ FIDH and LLP (2002), op. cit.

${ }^{40}$ Czech Republic Ministry of Interior, National Strategy on Policing Minorities, Prague, 2002, para. 2.4.
} 
attached to the justice ministry. Still, Czech NGOs maintained that arrangements for the investigation of complaints against the police continued to lack objectivity and credibility, and therefore did not adequately address the persistent problem of police impunity. ${ }^{41}$

When the final comprehensive monitoring report before Czech accession was issued in 2003, minority protection issues appeared as a relatively minor theme in comparison with earlier reports. The Commission noted under the section dealing with social policy that Czech antidiscrimination legislation had yet to be fully aligned with the acquis, that disproportionate unemployment persisted and that "the multi-faceted discrimination and social exclusion faced by the Roma continues to give cause for concern" ${ }^{42}$ It concluded that "considerable efforts should aim at improving the situation of the Roma minority". ${ }^{43}$ The Commission also noted that the police code of ethics still needed to be adopted, and its continuing absence was a "significant concern". It reiterated that measures to strengthen police capacities to investigate crimes by police officers were needed. ${ }^{44}$

When the Czech Republic gained membership of the EU in May 2004, it still did not have a comprehensive framework of anti-discrimination legislation in place but rather a fragmented or patchwork approach implemented through various legal regulations. Important lacunae remained in the lack of basic definitions of types of discrimination under Czech law. Gaps remained, for example, in the scope of the Charter of Rights and Fundamental Freedoms, which applied to the decisions of public authorities towards citizens, but according to the European Committee Against Racism and Intolerance (ECRI), not to relations between citizens, nor in establishing a legal basis for the awarding of compensation to victims of discrimination. The ECRI also specifically called for Czech judges to apply Charter anti-discrimination provisions to cases of racial discrimination perpetrated by public officials at local and national levels. ${ }^{45} \mathrm{~A}$ draft anti-discrimination law was eventually introduced in 2007, but was vetoed by President Klaus the following year on the grounds that the existing legislation was already adequate to ensure non-discrimination. At risk of being sanctioned with heavy fines by the European Commission for not implementing the obligations of the EU Race Equality Directive, the Czech Republic became the last EU member state to adopt comprehensive anti-discrimination legislation. ${ }^{46}$ Overriding the presidential veto, the Czech parliament adopted the legislation in June 2009, which introduced a broad prohibition on racial discrimination across multiple sectors, guaranteeing equal and effective protection against discrimination to all persons. Another related initiative took place in 2008, when a new Criminal Code was enacted, taking effect in January 2010, which strengthened existing criminal law provisions aimed at combating racially motivated offences. ${ }^{47}$

EU pressure was less successful in promoting change in Czech police relations with the Roma. A 2005 Council of Europe report referred to "the persistence of attitudes of intolerance and

\footnotetext{
${ }^{41}$ Council of Europe, Advisory Committee on the Framework Convention for the Protection of National Minorities, Second Opinion on the Czech Republic, ACFC/INF/OP/II(2005)02, adopted 24 February 2005, Strasbourg, paras. 95 and 98.

42 European Commission, Comprehensive Monitoring Report on the Czech Republic's Preparations for Membership 2003, Brussels, 2003, pp. 34-35.

43 Ibid., p. 35.

${ }^{44}$ Ibid., p. 46.

${ }^{45}$ European Commission against Racism and Intolerance (ECRI), Report on the Czech Republic, adopted 2 April 2009, ECRI, Brussels (2009), paras. 11 and 12.

${ }^{46}$ Milena Strafeldova, “Czech Republic Adopts Anti-Discrimination Act, Avoids European Commission Sanctions”, Czech Radio (online), 6 June 2009 (http://romove.radio.cz/en/clanek/22523).

${ }^{47}$ ECRI (2009), op. cit., para. 18.
} 
hostility on the part of certain police officers, extending to violence in some cases, towards persons belonging to more vulnerable groups, and particularly Roma”. It recommended closer monitoring, independent police oversight mechanisms to ensure the adequate and impartial investigation of any such incidents and sanctions where merited, as well as systemic human rights training and awareness-raising among police. ${ }^{48}$ From the EU side, the case for Czech police reforms in relations with the Roma and other marginalised groups could have been advanced more effectively. The Commission could have benefited from a more clearly conceptualised approach, such as framing the need and parameters for police reform within the more comprehensive framework of "democratic policing", which emphasises respect for the rule of law and human rights, police accountability and responsiveness to the needs of all citizens, including vulnerable groups and communities such as the Roma. ${ }^{49}$ More importantly, as reflected in the regular monitoring reports, because the Commission treated problems with police accountability, integrity and relations with the Roma minority for the most part as issues pertaining to the political conditions of the Copenhagen criteria, they lacked the more specific benchmarking and ultimately firmer leverage of the acquis. The Commission's assessments of candidate states' progress in meeting the political conditions tended to be broad, vague and unsystematic. The impact of the monitoring reports was also arguably diluted through their formulaic reiteration that "the Czech Republic continues to fulfil the Copenhagen political criteria" and specifically human rights, while repeatedly raising the issue of discrimination by public authorities, including lack of police and judicial impartiality towards Roma. ${ }^{50}$

The EU accession process was a generally positive influence in leveraging improved minority protection in the Czech Republic, inducing the Czech government to introduce various initiatives to improve the situation of the Roma. Criticism from the Commission also led in 2000 to the establishment of an institution that would prove important for protecting the rights of Roma, the Ombudsman's office, which had long been blocked by Klaus on the grounds that it was unnecessary. ${ }^{51}$ Thus in contrast to the absence or weakness of state protection mechanisms apparent in the 1990s, by 2004 the Czech government had revised or developed new legislation, and introduced numerous initiatives and policies to improve the situation of the Roma. Nevertheless, discrimination continued to be a problem and the Commission failed to exercise sufficient leverage, such as through linking human rights and minority protection more directly and effectively to police reform, especially through an effective police accountability system. This constituted a major missed opportunity to advance democratic policing and improve police relations with the Roma minority.

\subsection{Post-accession initiatives on the situation of the Roma}

In terms of important institutional and policy developments on the situation of the Roma since 2004, the position of minister for human rights and national minorities was established in January 2007, with the task of working to enhance respect for human rights, the development of civil society and the non-governmental sector. The minister deals with Roma affairs and other minority groups. The Czech government also established a Social Inclusion Agency in 2008, with the objective of providing a comprehensive approach to coordinating and improving social

\footnotetext{
${ }^{48}$ Council of Europe (2005), op. cit., para. 12.

49 David H. Bayley, Changing the Guard: Developing Democratic Police Abroad, Oxford: Oxford University Press, 2006, pp. 19-20.

${ }^{50}$ For example, European Commission, 2001 Regular Report on the Czech Republic's Progress Towards Accession, SEC (2001) 1746, Brussels, 13 November 2001, pp. 21-26.

${ }^{51}$ Isa Camyar, "Europeanization, Domestic Legacies and Administrative Reforms in Central and Eastern Europe: A Comparative Analysis of Hungary and the Czech Republic”, Journal of European Integration, Vol. 32, No. 2, 2010, pp. 150-51.
} 
integration efforts with respect to the Roma. In the area of education, the Czech government introduced reforms in response to a November 2007 judgment by the European Court of Human Rights that found the Czech Republic had violated the right of Roma children to an education free of discrimination. ${ }^{52}$ The government was required by the Strasbourg Court to implement corrective measures to the educational system that had funnelled Roma students disproportionately and often without adequate testing towards 'special schools' intended for mentally disabled students.

The ministry of interior has also implemented various mechanisms and programmes aimed at improving police-Roma relations. These include the establishment of Roma police assistants, who facilitate contacts between Roma and the police, assist Roma crime victims in filing a police report, educate victims about their legal rights and help police to investigate unreported crime in the Roma community. ${ }^{53}$ In addition, minority liaison officers facilitate communication between minority groups and the police, as well as between the police and local authorities and NGOs. The Czech police have also become more active in monitoring extremism, have developed specialised expertise on extremist crime and have responded more visibly to the threats of violence and harassment posed to Roma communities by demonstrations of neo-Nazis and other extremists. Following a series of anti-Roma public events in 2008 by extremists, the Czech interior ministry coordinated a meeting with Czech Roma representatives and NGOs to discuss how to ensure the safety of Roma communities. ${ }^{54}$ All Czech police now receive training on working with minorities, and as mentioned above, the Czech police have implemented various programmes aimed at increasing the representativeness of police personnel by recruiting more minority members, particularly Roma.

According to the Czech ministry of interior, the number of extremist crimes has undergone a steady overall decline. For example, according to official statistics the peak number of extremist crimes, 473, was recorded in 2002, declining to 196 in 2007. Nevertheless, it is worth noting that within the context of long-term decline, such crimes underwent a surge in 2008 to 217,, ${ }^{55}$ reflecting a resurgence of extremism and anti-Roma sentiment in certain countries across Europe ${ }^{56}$ A further indication of overall progress in the Czech state's approach was a ministry of interior initiative to dissolve the extremist Workers' Party, which was accepted on its second try by the Czech Supreme Administrative Court in March 2010, on the grounds that the party platform was xenophobic and racist. ${ }^{57}$ The Workers' Party had been involved in numerous antiRoma actions and demonstrations, including the organising of vigilante patrols targeting

\footnotetext{
52 See D.H. and others v. the Czech Republic (Application No. 57325/00), European Court of Human Rights Grand Chamber Judgment, November 2007.

${ }^{53}$ Immigration and Refugee Board (IRB) of Canada, Issue Paper, Czech Republic: Fact-Finding Mission Report on State Protection, IRB, Ottawa, June 2009.

${ }^{54}$ OSCE Office for Democratic Institutions and Human Rights (ODIHR), Hate Crimes in the OSCE Region - Incidents and Responses: Annual Report for 2008, ODIHR, Warsaw, November 2009, p. 35.

55 See Czech Republic Ministry of Interior, Information on the Issue of Extremism in the Czech Republic in 2007, Prague, 2008, Annex, Table 1; see also Czech Republic Ministry of Interior, Strategy for Combating Extremism - Year 2009, Prague, 2009, p. 14 (http://www.mvcr.cz/mvcren/article/documentson-the-fight-against-extremism.aspx).

56 See European Roma Rights Centre, "Roma Rights 1, 2009: Hard Times for Roma: Economics, Politics and Violence”, ERRC, Budapest, 30 July (http://www.errc.org/cikk.php?cikk=3046); see also Amnesty International, “Europe’s Roma Community Still Facing Massive Discrimination”, 7 April 2009.

57 “Czech court dissolves the Workers' Party”, Czech Republic Ministry of Interior (online article, undated) (http://www.mvcr.cz/mvcren/article/czech-court-dissolves-the-workers-party.aspx).
} 
Roma, ${ }^{58}$ and in May 2009 had run a campaign advertisement for the European Parliament promising a "final solution to the Gypsy question". 59

\subsection{Current situation of the Roma minority}

Despite the numerous changes implemented by Czech state authorities both during the accession process and since becoming an EU member state in 2004, the situation of the Czech Roma in 2010 remains perilous in many respects. Czech Roma are still largely segregated in terms of housing and education. Many Roma live in substandard, racially segregated lowincome housing and neighbourhoods that have been termed 'socially excluded localities' ${ }^{60}$ According to an authoritative 2006 study, an estimated 80,000 Roma live in these ghettos or socially excluded localities, or more than one-third of the total Roma population. ${ }^{61}$ De facto segregation is a result of several factors implicating state policies. ${ }^{62}$ Due to the 1993 Citizenship Law, many Roma were unable to claim Czech citizenship and consequently lacked access to social benefits, including rent allowances. Many Roma who lacked the necessary documentation because of having been transferred from Slovakia during the communist period became vulnerable to eviction by landlords. Moreover, municipal authorities frequently impose requirements that in practice restrict the ability of Roma to qualify for social housing, such as 'moral behaviour' and full employment. In consequence, the most deprived, overcrowded and unsanitary accommodation in the Czech Republic is overwhelmingly occupied by Roma, especially those who have been evicted or unable to access state-subsidised housing. Although discrimination based on ethnicity in housing is prohibited by law, certain municipalities continue to apply municipal regulations that discriminate against Roma. ${ }^{63}$ Czech Roma report high levels of perceived discrimination based on ethnic origin in housing, with $83 \%$ of respondents in 2008 reporting widespread discrimination (surpassed in the EU only by the Hungarian Roma at $90 \%){ }^{64}$

Irrespective of the recent educational reforms prompted by the Strasbourg Court decision discussed above, Roma children continue in practice to be segregated in schools for children with mental disabilities (the former 'special schools', subsequently renamed 'practical schools'), or in schools and classes that tend to offer an inferior education. ${ }^{65}$ Approximately $27 \%$ of Roma children attend 'practical schools', compared with $2 \%$ of non-Roma children. ${ }^{66}$

\footnotetext{
58 Amnesty International, Amnesty International Report 2010 - Czech Republic, Amnesty International, London, 2010(a).

${ }^{59}$ Freedom House, Freedom in the World 2010 - Czech Republic, Freedom House, Washington, D.C., 2010.

${ }^{60}$ See the interactive mapping of Roma socially-excluded localities across the Czech Republic, by the Joint Project of the European Social Fund, Czech Ministry of Labour and Social Affairs, and Gabal Consulting (http://www.esfcr.cz/mapa/int_CR.html).

61 US Department of State, 2009 Country Reports on Human Rights Practices - Czech Republic, Washington, D.C., 11 March 2010.

62 O’Nions (2007), op. cit., p. 111.

${ }^{63}$ US Department of State (2010), op. cit.

${ }^{64}$ European Union Fundamental Rights Agency (FRA), Housing discrimination against Roma in selected EU Member States: An analysis of EU-MIDIS data, Conference edition, FRA, Vienna, October 2009(b), p. 13.

65 Amnesty International, Injustice Renamed: Discrimination in Education of Roma Persists in the Czech Republic, EUR 71/003/2009, Amnesty International, London, January 2010(b), p. 4.

${ }^{66}$ US Department of State (2010), op. cit.
} 
Roma continue to be targets of extremist violence. In April 2009, a Roma family home in Vitkov was destroyed by Molotov cocktails. A two-year old child suffered severe burns to $80 \%$ of her body and her parents were seriously injured. Four far-right extremists have been convicted and handed sentences of up to 22 years. ${ }^{67}$ The near-lethal consequences of the Vitkov attack have apparently sensitised Czech media and public attention to the practice of firebombing Roma homes, which now receives more media coverage than earlier. ${ }^{68}$ Nevertheless, such extremist violence has not been eradicated and Czech Roma have continued to be targeted by extremists, including by arson attacks. ${ }^{69}$

Violent anti-Roma demonstrations continue to be held by neo-Nazi, skinhead and other extremist groups in the Czech Republic. One demonstration against the Roma was organised in Litvinov with the support of the Workers' Party in autumn 2008, involving at least 350 extremists and the enthusiastic involvement of several hundred local participants. ${ }^{70}$ In another mass demonstration, the police used force to prevent extremist violence against the local Roma community in Janov. Yet charges against 15 protesters were subsequently dropped by the state prosecutor and the only persons convicted in the clashes were two Roma, who were sentenced to 400 hours of community service for physically and verbally assaulting members of the Workers' Party. ${ }^{71}$

Although the Czech Republic has criminalised racially motivated offences, many Roma remain reluctant to report such racially motivated crimes owing to the fear of or lack of trust in the police. The Czech police, as mentioned above, have previously been accused of mistreating minority members, predominantly Roma, and existing systems of police accountability have in the past generally failed to hold officers to account for such misconduct. The ECRI has noted that the Czech police and judiciary require an excessively high standard of proof to establish that an act was based on racist motivation, ${ }^{72}$ contributing to the still unsatisfactory implementation of criminal law provisions against racism. Among ethnic minority groups experiencing discrimination in the EU, the Czech Roma were found to be the least likely to report "in-person crime" (assault, threat or harassment of a serious nature) to the police (87\%) because they had no confidence in the police's ability to respond effectively to the needs of the Roma community as victims of crime ${ }^{73}$ or because they feared intimidation by the perpetrators $(51 \%){ }^{74}$ A reported $56 \%$ of Czech Roma do not trust the police, a rate surpassed among minority groups in Europe only by the Roma in Poland. ${ }^{75}$ Czech Roma were also among those

\footnotetext{
${ }^{67}$ See the article, “Czech neo-Nazis jailed for Roma attack”, BBC News (online), 20 October 2010.

68 Sarah Borufka, "Police investigate latest attacks against Romanies”, Radio Prague, 6 April 2010 (http://romove.radio.cz/en/article/23183).

69 See for example Borufka (2010) supra and also Chris Johnstone, "Police mobilised to investigate Ostrava arson attack on Roma family”, Radio Prague, 16 March 2010 (http://romove.radio.cz/en/article/23127).

${ }^{70}$ Czech Republic Ministry of Interior, Strategy for Combating Extremism - Year 2009, Prague, 2009, pp. 4-5 (http://www.mvcr.cz/mvcren/article/documents-on-the-fight-against-extremism.aspx).

${ }^{71}$ US Department of State (2010), op. cit.

72 ECRI (2009), op. cit., para. 21.

${ }^{73}$ European Union Agency for Fundamental Rights (FRA), EU-MIDIS: European Union Minorities and Discrimination Survey - Main Results Report, Conference edition, FRA, Vienna, 2009(a), p. 170. A definition of "in-person crime" is given on p. 15.

${ }^{74}$ Ibid., p. 170.

${ }^{75}$ Ibid., p. 151.
} 
who most felt they had been ethnically profiled or singled out by the police because of their ethnicity (52\%), and reported the highest rates of profiling by border police (48\%) ${ }^{76}$

Numerous domestic and international observers have also noted the increasing frequency of anti-Roma hate speech in public discourse in the Czech Republic, including by senior politicians, government ministers and local officials and by candidates in election campaigns. ${ }^{77}$ According to Human Rights First,
the regular and systemic human rights abuses against Roma in the Czech Republic are aggravated by the fact that anti-Romani hate speech is a regular part of the public discourse in the country. Anti-Romani statements are a standard and often unquestioned part of public life in the Czech Republic, and officials as high-ranking as the Prime Minister, the President, Senators (including members of the Senate's Human Rights Committee), other members of the cabinet, and many local officials have either made anti-Romani statements or failed to counteract speeches denigrating the dignity of the Roma. ${ }^{78}$

An extensive pan-European survey on discrimination against minorities conducted in 2008 by the EU's Agency for Fundamental Rights found that Roma in the Czech Republic experienced the highest overall level of discrimination (64\%) over a 12-month period among the top ten minority groups experiencing discrimination in member states. ${ }^{79}$ The survey showed that Czech Roma consistently placed at or near the top level of discrimination across multiple categories compared with other national, ethnic-minority groups across the EU. Czech Roma were among those who most frequently reported experiencing discrimination at work (27\%) and discrimination at a café, restaurant, bar, nightclub or shop (30\%). Czech Roma were also among the top minority groups reporting being victims of crime (46\%) among the surveyed minority groups in the EU. Czech Roma reported the third highest rate of experiencing assault or threat in the EU, with 42 incidents for every 100 respondents over the preceding year. Additionally, 31\% of Czech Roma reported experiencing serious harassment at least once over the past 12 months, with 118 incidents recorded for every 100 respondents. Notably, 32\% of Czech Roma reported that they had been the victim of a 'racially motivated' assaults threats, or serious harassment over the past 12 months, the highest rate in the EU, tying with the rate experienced by the Somali minority in Finland. ${ }^{80}$ Furthermore, 55\% of Czech Roma respondents reported receiving threats involving physical violence, the second highest rate in the EU. The survey found that $25 \%$ of assaults and 35\% of harassment incidents reported by the Czech Roma were perpetrated by members of a racist gang. ${ }^{81}$

Czech Roma respondents revealed high levels of discrimination across multiple domains, with 580 incidents per 100 respondents reported over a 12-month period. More specifically, 45\% of Czech Roma reported experiencing discrimination in employment, the second highest rate among minority groups in the EU. They also reported the second highest rate of discrimination by social service personnel at $21 \%$, and the fifth highest rate of discrimination by school personnel at $11 \%$. One of the few bright spots in the survey results was that Czech Roma were more likely to report incidents of discrimination to the authorities (34\%) than some of the other

\footnotetext{
${ }^{76}$ Ibid., pp. 172-173.

${ }^{77}$ ECRI (2009), op. cit., para. 43.

${ }^{78}$ Human Rights First, 2008 Hate Crime Survey: Roma and Sinti, Human Rights First, New York, NY, 2008.

${ }^{79}$ European Union Agency for Fundamental Rights (2009a), op. cit., p. 9.

${ }^{80}$ Ibid., pp. 10-16.

${ }^{81}$ Ibid., pp. 167-169.
} 
minority groups in the survey, suggesting greater awareness of their rights and of mechanisms for reporting discrimination in the Czech Republic than elsewhere. ${ }^{82}$

Still, only $24 \%$ of Czech Roma could specifically name an organisation that offered support or advice to victims of discrimination. Czech Roma were also the most aware of antidiscrimination law concerning the workplace (57\%), although only $40 \%$ were aware of such law regarding social services and only $36 \%$ believed legislation against discrimination existed with regard to letting or selling property. ${ }^{83}$ Summing up its findings on the discrimination experienced by Roma when looking for work, attempting to patronise bars and restaurants, and interacting with social service personnel, the survey report concluded that "[r]elative to some of the other six Member States where the Roma were surveyed, the situation in the Czech Republic is considerably worse". ${ }^{84}$

\section{The response of the Canadian government to Roma asylum claims, 1997-2010}

\subsection{Canadian refugee system 1997-2010}

Canada has, like other industrialised receiving states, experienced growing tension between its commitments under the international refugee regime and concerns about strengthening sovereign state control over its borders. This tension was reflected in the Canadian government's response to an earlier influx of Czech Roma who lodged refugee claims in Canada. In 1997, following the broadcast of a Czech television documentary about Canada's liberal asylum policy and the positive experience of certain Czech Roma refugee claimants, some 1,500 Czech Roma arrived in Canada and applied for refugee status. The surge triggered a media frenzy, including racist discourse about a 'gypsy invasion' and concerns articulated by some public officials about the influx of criminally-oriented individuals. ${ }^{85}$ The wave of Czech Roma refugee claimants prompted the unprecedented introduction of criminal checks on all Czech Roma from August 1997, conducted by the Citizenship and Immigration Department. (These checks were subsequently found to be in violation of the Canadian Charter of Rights and Freedoms. The criminal checks also failed to turn up any significant criminal records among the Czech Roma refugee applicants. $)^{86}$ The Canadian government imposed a visa requirement on Czech nationals on 8 October 1997, which effectively stopped the flow of Czech Roma refugee applicants. However, assertions that the Czech Roma were merely economic migrants were refuted by the decisions of the Canadian Immigration and Refugee Board (IRB), an independent, quasi-judicial administrative tribunal, which subsequently granted refugee status to the vast majority (over 85\%) of Czech Roma who had applied for asylum in Canada in 1997. ${ }^{87}$ In one of its final hearings on the 1997 applicants, the IRB found that " $[t]$ he harm which they fear, discrimination and harassment on a cumulative basis, as well as violence at the hands of the skinheads, represents serious harm which, in our opinion, amounts to persecution" ${ }^{88}$ The visa requirement nevertheless remained in place for ten years, with Canada only lifting the visa

\footnotetext{
82 Ibid., p. 42-50.

${ }^{83}$ Ibid., p. 158-159.

${ }^{84}$ Ibid., p. 161 (emphasis in the original).

85 Stephane Lefebvre, "Recent research: Roma and the Czech-Canadian visa issue, 1998-9", Contemporary Politics, Vol. 9, No. 3, September, 2003, p. 319.

${ }^{86}$ Ronald Lee, "Post-Communism Romani Migration to Canada”, Cambridge Review of International Affairs, Vol. XIII, No. 2, 2000, p. 57.

${ }^{87}$ Ibid., $43 n$.

${ }^{88}$ Lila Sarick, “Gypsies real refugees, immigration body rules”, Globe and Mail, 24 April 1998, A4.
} 
requirement on 31 October 2007, in response to EU pressure after the Czech Republic had become a member of the EU in 2004 and part of the Schengen area in 2007.

By 2008, growing numbers of Czech Roma had again begun to arrive in Canada and apply for refugee status. Canada eventually reimposed the visa requirement for Czech nationals in July 2009 as a means to stem the flow. Between the lifting of the visa requirement in October 2007 and May 2010, some 3,000 refugee claims had been initiated by Czech nationals in Canada, the vast majority of whom were Roma, and almost all of whom were registered before the visa was reimposed in 2009. ${ }^{89}$ The Harper government, specifically the Minister of Citizenship, Immigration and Multiculturalism, Jason Kenney, asserted that the Czech Roma were not legitimate refugees, contradicting the findings of earlier decisions made by both the IRB and the Federal Court of Canada, which established certain Czech Roma to be refugees at risk of serious harm. ${ }^{90}$ Blurring the line between the distinct regimes that exist for immigration and for asylum, Kenney declared in 2009:

I'm the minister responsible for over 900,000 people around the world who are patiently waiting in the queue to come to Canada, on average taking five-plus years to arrive here as permanent residents...I cannot tolerate a situation where they see people simply getting a plane ticket, arriving here, saying the magic word 'refugee', getting quasi-landed status, getting a work permit and/or welfare benefits. That is an insult to the millions of people who aspire to come to Canada legally. ${ }^{91}$

Kenney went on to assert that Canada's asylum system created a de facto "two-tier immigration system: a slow one for law-abiders and a fast one for lawbreakers". ${ }^{92}$

Aside from the highly specialised community of immigration lawyers, refugee experts and advocates, and despite the high level of media attention the Czech refugee applicants had attracted, the disjuncture between the minister's remarks on the alleged lack of legitimacy of Czech Roma claims and the IRB's past practice in recognising such claims went largely unremarked by the Canadian media and public. The reimposition of the visa nonetheless caused bilateral political tensions for Ottawa with Prague and the EU. As a relatively new member of the EU who had also recently become part of the Schengen zone, the Czechs maintained that Canada could not single it out and impose visas against its citizens without applying the visa requirement across the board to all EU member state citizens. Although the Czech government responded by exercising its prerogative to impose a visa requirement on Canadian diplomatic and military personnel, it was unable to take further unilateral action on imposing a general visa on other Canadian citizens, since visa policy for EU member states is no longer a national decision but a matter determined by the EU.

In March 2009, the IRB sent a fact-finding team to the Czech Republic to interview numerous governmental and non-governmental sources and experts, and produced two issue papers, one on state protection published in June $2009,{ }^{93}$ and the other on the situation and treatment of the Roma published in July 2009. ${ }^{94}$ Both were completed and made publicly available shortly after the Canadian government reimposed visa requirements on Czech nationals. Following publication of the first report outlining measures implemented by the Czech government in

\footnotetext{
${ }^{89}$ See Nicholas Keung, “Czech, Mexican refugee claims plummet”, Toronto Star, 23 March 2010, p. 4; see also “MEPs ask Canada to lift visa requirements for all EU citizens”, EurActiv, 6 May 2010.

${ }^{90}$ Peter Showler, “The bogus refugee myth”, Ottawa Citizen, 12 August 2009.

${ }^{91}$ Nicholas Köhler, “A crack-down on queue-jumpers”, Maclean’s, 3 August 2009, p. 19.

92 Ibid.

${ }^{93}$ Immigration and Refugee Board (IRB) of Canada (2009), op. cit.

${ }^{94}$ Ibid.
} 
recent years to address discrimination and improve the situation of the Roma, the Canadian immigration minister asserted that the IRB report supported his contention that Czech Roma do not face state-sanctioned discrimination, stating that "the Czech Republic is a full member of the EU and in compliance with the European human rights law, and I think the report underscores that there is no policy of state-sponsored persecution against Czech Roma”. ${ }^{95}$

Yet a close reading of the IRB reports on state protection and the situation of the Roma does not unequivocally lead to the conclusions drawn by the minister. The research reports together set out both measures implemented by the Czechs and continuing problems experienced by the Czech Roma minority. Although the authors of the reports refrained from drawing conclusions about whether state protection was adequate, possibly because Canada's refugee determination process has traditionally placed strong emphasis on the experiences of each individual claimant, the reports contained substantial evidence of continuing discrimination and marginalisation of the Czech Roma. Also contrasting with the minister's interpretation, reports by Canadian news media interpreted the findings of the IRB studies to mean that the Czech Roma were oppressed. ${ }^{96}$

The discrepancy in interpreting the findings may also be explained by the immigration minister's failure to apply a more fine-grained explanation of state protection. According to Peter Showler, former chairman of the IRB, a key issue with regard to the Czech Roma (and Mexican $)^{97}$ refugee claims is not whether the government is persecuting its citizens, but "whether they have the capacity to protect those citizens who are threatened with persecution by others". ${ }^{98}$ Showler refers to the continuing problem in both the Czech Republic and Hungary of anti-Roma violence inflicted by members of far-right and extremist groups. State protection, in other words, consists not only of the absence of a deliberate policy of persecution implemented by state agents as underscored by the immigration minister, but also efforts by the state to prevent, punish and provide redress for the harmful actions of non-state actors - i.e. other citizens. In this respect, despite numerous legislative changes and policies introduced by the Czech government especially after 1997, the IRB reports buttress the findings of human rights groups and public opinion polls (such as the EU-MIDIS survey) that Czech Roma continue to be subject to widespread discrimination, marginalisation and violence.

Canadian refugee policy reflects two broader trends visible among receiving industrialised states. First, over the long term there has been a progressive liberalisation of asylum achieved primarily through court decisions that have broadened the refugee definition to previously excluded categories of applicants. Various liberal interpretations of the refugee definition developed through Canadian jurisprudence have specifically influenced refugee practices in other common law jurisdictions. ${ }^{99}$ For example, the widely-cited Canada (Attorney-General) $v$. Ward decision of the Supreme Court of Canada clarified various issues pertaining to agents of

\footnotetext{
95 See “Kenney denies Roma face discrimination”, Ottawa Citizen, 26 June 2009, A3.

${ }^{96}$ See Juliet O’Neill, “Refugee board suggests Czech Roma oppressed; Findings come as Tories move to reduce numbers coming to Canada”, Ottawa Citizen, 28 July 2009, A6; see also Calvin White, “Czech Gypsies turn to Canada for protection from discrimination; Canadian investigators find persecution, but Ottawa loath to grant asylum”, Edmonton Journal, 14 July 2009, A16.

97 At the same time that the Czech Roma were making refugee claims, Canada experienced a surge in Mexican refugee applicants, many of whom claimed to be fleeing violence by drug gangs and organised crime. The Canadian government similarly imposed a visa requirement on Mexican nationals.

${ }^{98}$ Peter Showler, “Invalid claims about refugees”, Ottawa Citizen, Special, 17 July 2009.

99 Audrey Macklin, “Asylum and the Rule of Law in Canada: Hearing the Other (Side)”, in Susan Kneebone (ed.), Refugees, Asylum Seekers and the Rule of Law: Comparative Perspectives, Cambridge: Cambridge University Press, 2009(a), pp. 93-94.
} 
persecution, unwillingness or inability to protect, burdens of proof regarding state protection, the definition of a particular social group and the scope of political opinion. Beyond offering asylum to persecuted people, Canada's Immigration Law (2001) also offers asylum to those who face a substantial risk of torture, a risk to their lives or a risk of cruel or unusual treatment or punishment against which the state is unable or unwilling to provide protection (with the exception of states unable to provide adequate health or medical care). ${ }^{100}$ Additionally, certain Canadian administrative guidelines of the IRB have broadened the interpretation of refugee. The IRB developed a gender-sensitive approach to interpreting the Convention's refugee definition through its 1993 Gender Guidelines, which became widely emulated. The Guidelines established, for example, that harm inflicted mainly on women and girls, such as rape, sex trafficking and female genital mutilation, constituted persecution. It similarly established that refusal to abide by religious rules might constitute a political opinion.

The second, more recent trend reflected in Canadian practice as well as that of other industrialised receiving states is one of imposing greater restrictions on asylum, aimed at limiting protection responsibilities by deterring or deflecting asylum seekers. ${ }^{101}$ This trend has been driven by various factors, such as the resistance of receiving state populations and governments to the higher numbers of refugee claimants seen since the $1980 \mathrm{~s}$, as well as concerns about 'irregular' migration, the economic and cultural integration of foreigners, and especially in the aftermath of the 11 September 2001 attacks and ensuing 'war on terror', national security. Restrictive measures include imposing barriers to entry, most commonly visa requirements but also physical interceptions. States have developed more arduous procedures for claiming asylum, such as shorter time periods in which to file applications and therefore less opportunity for applicants to gather and provide supporting documentation. Receiving states may detain asylum-seekers while their status is being determined, including in offshore processing centres. Further restrictive measures include reducing the rights and benefits refugee claimants enjoy while waiting for their applications to be determined, and accelerating the determination process while minimising applicants' access to judicial review.

It has also become common to apply 'safe country of origin' practices, in which receiving states identify a list of countries considered to generally respect human rights and to not produce refugees. Refugee applicants from countries on the safe country list are subject to an accelerated determination procedure, during which they have little time to collect and file the necessary documentation and often lack legal counsel, making it less likely that they can prove their country was unsafe and that their claim will be accepted. Through 'safe third country' practices, receiving states also deny certain categories of refugee claimants the right to an individual determination of their status, refusing their responsibility to process an asylum seeker if protection can be sought by him or her from a safe alternative country. In addition, receiving states are increasingly using 'temporary protection' status. This array of measures contributed to sharply decreasing refugee applications in industrialised countries for several years after 2002. ${ }^{102}$

\footnotetext{
100 See the Immigration and Refugee Protection Act 2001, section 97(1); see also Immigration and Refugee Board (IRB) of Canada, Consolidated Grounds in the Immigration and Refugee Protection Act, IRB, Ottawa, 15 May 2002.

101 Matthew E. Price, Rethinking Asylum: History, Purpose, and Limits, Cambridge: Cambridge University Press, 2009, pp. 8-9.

102 Ninette Kelley, “International Refugee Protection Challenges and Opportunities”, International Journal of Refugee Law, Vol. 19, No. 3, 2007, p. 426.
} 


\subsection{Bill C-11: Reforming the Canadian refugee system}

Since the re-emergence of controversy surrounding the Czech Roma refugee applicants in 2008, the Conservative government has introduced reforms to the refugee system, namely through the passage in June 2010 of new legislation, Bill C-11, the Balanced Refugee Reform Act, to replace the former Immigration and Refugee Protection Act of 2001. ${ }^{103}$ Bill C-11 introduced some long-delayed reforms including the creation of the Refugee Appeal Division within the IRB. At the same time it also introduced several measures that have reinforced the trend of restricting asylum through administrative mechanisms, which has raised concerns about the fairness and effectiveness of the refugee determination process. One such measure is the move to significantly shorten timelines for an interview to take place, which must now occur within 15 days after arrival and with a hearing within 90 days. Such shortened timelines pose serious obstacles to the marshalling of evidence by claimants. ${ }^{104}$ The government also maintained the move towards single-member panels that rule on refugee claims in a bid for greater efficiency, although these have been criticised by former IRB commissioners on the grounds that they diminish the quality of reasoning and result in more incorrect decisions in often highly complex refugee cases. ${ }^{105}$

Furthermore, Bill C-11 deepened concerns about Canada's commitment to the fundamental principles of the refugee Convention, through the Bill's provision for a list of 'designated countries' that would be used to further screen out refugee applicants. According to the immigration ministry's website, designated countries are those that "do not normally produce refugees, that have a robust human rights record and offer strong state protection. States with strong democratic, judicial and accountability systems are likely to provide the necessary protection to their citizens." ${ }^{, 106}$ While it was under consideration the proposed measure prompted the head of the division of international protection of the United Nations High Commissioner for Refugees to caution that even people from a designated safe country of origin may have a legitimate need for protection and therefore a basis for claiming asylum, and that this measure, if implemented, would need to be accompanied by a review mechanism to correct potentially erroneous decisions. ${ }^{107}$ The amended Bill C-11 accordingly included this possibility of review, with rejected claimants from designated safe countries entitled to appeal to a new division of the IRB and with the processing of their appeals being expedited (30 days), allegedly to "discourage people from those countries from applying in the hopes of dragging out appeals for years". ${ }^{108}$ Refugee claimants from designated safe countries will initially have only 60 days to receive a hearing. Critics nevertheless maintain that the designation of safe countries or democratic states viewed as having sound human rights records would in effect constitute a bar on appeal for selected nationalities or groups of claimants. This situation would run counter to

103 Canada, Immigration and Refugee Protection Act, Bill C-11 (http://www2.parl.gc.ca/HousePublications/Publication.aspx?DocId=2330877\&Language=e\&Mode=1).

104 Amnesty International, Canadian Council for Refugees, Refugee Lawyers’ Association of Ontario, "Bill C-31 Needs Thorough Review”, Joint Public Statement, 27 April 2010.

105 See Peter Showler, "Submission to the Standing Committee on Citizenship and Immigration”, 29 March 2007 (http://www.ccrweb.ca/documents/showler07.pdf); see also Audrey Macklin, "Refugee Roulette in the Canadian Casino", in Jaya Ramji-Nogales, Andrew I. Schoenholtz and Philip G. Schrag (eds), Refugee Roulette: Disparities in Asylum Adjudication and Proposal for Reform, New York and London: New York University Press, 2009(b), pp. 146-47.

106 See "Designated countries of origin" on the Citizenship and Immigration Canada website (http://www.cic.gc.ca/english/refugees/reform-safe.asp).

107 Anca Gurzu, “UNHCR calls for safe country review mechanism”, Embassy, 19 May 2010.

108 Gloria Galloway, “Jason Kenney trumpets hard-fought immigration reform”, Globe and Mail, 29 June 2010. 
the Convention's emphasis on determining a refugee claim on its individual merits, and undermine the neutral, human-rights focused basis of determining refugee status. ${ }^{109}$

The Conservative government has also engaged in rhetorical practices that risk conflating immigrants and refugees in the mind of the public. While Kenney's invoking of "illegal immigration" and "bogus" refugees is by no means unique among opinion leaders and decisionmakers in Western industrialised states, Canada has lacked an informed public debate on immigration and asylum policy issues. Bill C-11 was unprecedented in how it was tabled, without the accompanying processes of public consultation or dialogue seen with previous Canadian initiatives on immigration reform. ${ }^{110}$

The Canadian public debate surrounding the Czech Roma issue has also been influenced by an ambiguous use of IRB statistics to support contradictory claims. In justifying the imposition of visas against Czech nationals, Kenney cited the high rate of rejection or abandonment of refugee claims by Czech Roma once they were in Canada as evidence that their claims of persecution lacked legitimacy. Kenney maintained that the IRB's acceptance of $40 \%$ of Czech Roma refugee claims "masks the troubling fact that more than half of the claims are abandoned or withdrawn before a final decision is made by the Immigration and Refugee Board". ${ }^{111}$ Yet the use of statistics in this area can be highly misleading. In 2008 there were 853 refugee claims from Czech nationals. The IRB does not disaggregate claims according to ethnicity, but it is a reasonable assumption that the vast majority if not all of the claimants were Czech Roma. In 2008 the IRB approved 84 refugee claims from the Czech Republic, while 5 were rejected. Additionally, 11 claims were abandoned and 95 withdrawn before the IRB came to a final decision. ${ }^{112}$ The refugee acceptance rates cited often take into account only those claims in which a decision to accept or reject has been reached by the IRB, not counting those withdrawn or abandoned before the adjudication process ends in a decision. ${ }^{113}$ On those grounds, $94 \%$ of Czech claimants were granted refugee status in 2008. In the first six months of 2009, of the 90 refugee claims brought by Czech Roma that were considered by the IRB, the IRB approved 72 of them, an acceptance rate of $80 \% .{ }^{114}$ Once the Canadian government reimposed the visa, however, acceptance of Czech refugee claims dropped to 30\% between July and September. ${ }^{115}$ According to another report, the total percentage of approved Czech refugee claims for 2009 was $10 \%$, compared with $43 \%$ approved in $2008 .^{116}$

It would be disingenuous to assert that claims were abandoned or withdrawn mainly by those who submitted 'false claims' or who were 'economic migrants'. The issue of the abandonment of claims, which was raised by the minister as a reason to believe that the Czech Roma claims

\footnotetext{
109 Amnesty International et al. (2010), op. cit.

${ }^{110}$ Catherine Dauvergne, "Refugee reform is a mixed bag that needs to be aired”, Refugee Forum, Human Rights Research and Education Centre, University of Ottawa (http://www.cdphrc.uottawa.ca/eng/project/refugee-forum/publications/CDopinion.php).

${ }^{111}$ Peter O’Neil, “Canada clamps down on refugee claims”, CanWest News, 13 July 2009.

112 Peter O’Neil, “Canada interfering with rights of Roma refugees, group charges”, Ottawa Citizen, 6 May 2009, A10.

113 See comments by Canadian government lawyer Amina Riaz in Nicholas Keung, "Refugee challenges minister's 'bias””, Toronto Star, 23 March 2010, p. 4.

${ }^{114}$ Max Berger, "Speed up the refugee process, instead of requiring visas”, Montreal Gazette, 24 July 2009.

${ }^{115}$ Nicholas Keung, “Czech, Mexican refugee claims plummet”, Toronto Star, 27 January 2010, A15. 116 Ibid.
} 
were illegitimate, is rarely explored in depth in media accounts. ${ }^{117}$ Notably, however, similar claims made about the 1997 influx of Czech Roma suggests that factors other than the intention to deceive by lodging unjustified claims of persecution lie behind abandoned claims. Certain Czech Roma arriving in Canada in 1997 were allegedly treated in an intimidating manner, subjected to background criminal checks, and provided with false information, for example being informed by certain airport immigration officials that they would not be provided with housing and would be forced to live on the street. ${ }^{118}$ For some 600 Czech Roma from the 1997 influx who returned to the Czech Republic without pursuing their refugee claims, perhaps the primary factor behind their abandoned bids for refugee status was the denial of permission to the families of the asylum seekers to join them in Canada, and thus the prospect of a long period during which many families would remain divided between Canada and the Czech Republic. ${ }^{119}$ In numerous cases, Czech Roma had arrived unaccompanied by their spouses or children (or both), in anticipation of bringing over their families once they were established. ${ }^{120}$ By imposing criminal checks that were applied to all Czech Roma refugee claimants, the processing of claims was significantly delayed. Imposing the visa requirement in October 1997, the Canadian government effectively halted the influx of Czech Roma refugee claimants, and hence the possibility that families could be reunited in the short to medium term without returning to the Czech Republic. A similar dynamic may reasonably be assumed to apply to the 2008-09 wave of refugee claimants who arrived before the reimposition of the visa requirement.

Finally, the persistent evoking of queue-jumpers and bogus refugees by the immigration minister elicited charges of political interference in the refugee claims process by a former IRB chair, Roma interest groups and refugee lawyers, and resulted in a lawsuit launched by Roma Canadians against Kenney and the IRB for "institutional biases" that have been introduced into the IRB's decision-making. ${ }^{121}$ Of special concern is the role of the Canadian government in the appointment and reappointment of IRB commissioners. According to Audrey Macklin, a Canadian expert in refugee law and a former member of the IRB,

\begin{abstract}
[w] hen the minister pronounces on the validity, or lack thereof, of refugee claimants from any country without having heard the particular case and knowing the individual circumstances, there is the risk that individual decision makers whose jobs ultimately depend on the minister's decision to appoint and reappoint them, will be unduly influenced. They might be fearful when their time comes up for reappointment that he will examine their acceptance rates from the countries where he has deemed refugee claimants to be bogus, and penalize them. ${ }^{122}$
\end{abstract}

In summary, the Canadian governmental response to the 2008-09 influx of Czech Roma refugee claimants included the erection of barriers to entry through the reimposition of the visa and the portrayal by the immigration minister of such claims as illegitimate. The subsequent reform of the refugee system introduced measures, in particular the notion of a list of 'designated countries', that are likely to significantly constrain the ability of European Roma to seek asylum in Canada in the future. This response may be viewed in a wider context of the Canadian government's efforts to bolster sovereign control through exclusionary measures

\footnotetext{
${ }^{117}$ For example, see the editorial "No threat to true refugees", Globe and Mail (Toronto), 26 August 2009, A16.

${ }^{118}$ See “Roma exodus to Canada II”, RomNews Network Community (online), 29 August 1997.

${ }^{119}$ See “Romanies come home”, Radio Prague, 15 June 1998 (http://www.radio.cz/en/news/17902).

${ }^{120}$ Lee (2000), op. cit., p. 61.

${ }^{121}$ See O’Neil (2009), “Canada interfering with rights of Roma refugees”, op. cit.; see also Michelle Collins, "Political interference crippling refugee board: Former Chair”, Embassy, 22 July 2009.

122 Collins (2009), supra.
} 
restricting refugee movements to Canadian territory. The response also reflects the diminished priority accorded to human rights protection and promotion by the current Canadian government in comparison with previous governments. ${ }^{123}$ While domestic critics rightly point to the risk of further politicisation of the refugee determination process, an adjudicatory process intended to be independent, underlying this and the related exclusionary measures would appear to be a weakening of Canada's commitments under international law to offer state protection to those denied this in their home states. The growing inclination of Canadian leaders and those of other Western receiving states to conflate refugees with irregular migrants and mounting efforts to counteract uncontrolled migration through the use of visas have made it more difficult for refugees to reach protection.

\section{Conclusion}

The paper has outlined, first, how the Czech government has implemented a growing number of legislative and policy changes to improve the protection of human rights and the condition of the Roma since 1997. These human rights and minority protection norms were advanced, albeit somewhat ineffectively, through the comparatively soft leverage of political conditionality embedded within the EU accession process. Still, despite various reforms and initiatives introduced by Prague, the Roma continue to experience widespread discrimination in both the public and private sectors and remain vulnerable to physical violence from non-state actors, especially members of extremist movements and organisations. Whether state protection is sufficient has become more challenging to discern today because of the succession of policies and legislation introduced by Prague to address anti-Roma discrimination and violence. Efforts have been made to make Czech law enforcement and the criminal justice system more representative, sensitive and responsive to discrimination and to ethnic-based crime and violence. Nevertheless, the overall effectiveness of these initiatives must be questioned. The Czech Roma remain severely marginalised in socio-economic terms, experience continued discrimination in their daily lives, are the subject of public, often uncensored hate speech, and individually and communally continue to be vulnerable to racist violence. Self-perceptions of vulnerability and marginalisation by the members of this group further suggest that laws and policies have yet to effect change the day-to-day reality of most Czech Roma.

The paper has secondly outlined how the Canadian government's response to the 2008-09 influx of Czech Roma refugee claimants and recent developments in practices and legislation on refugees suggests a weakening of Canada's commitment to provide state protection to refugees under the international refugee Convention. The public questioning by the Canadian immigration minister of the legitimacy of Roma claims before the IRB was able to hear those claims and issue individual judgements was construed as political interference in the purportedly independent refugee determination process. Subsequent reforms to the refugee system confirmed weakening and politicising tendencies, and created new barriers to entry specifically through the new ministerial practice of ‘designating' (supposedly safe) countries.

The Czech Roma refugee issue also demonstrates the interplay and conflicting dynamics of two emergent paradigms of human rights and territorial sovereignty. ${ }^{124}$ The human rights paradigm, which emphasises the inclusive scope of human rights and their applicability to all individuals

123 Susie Alegre, The EU's External Cooperation in Criminal Justice and Counter-terrorism: An assessment of the human rights implications with a particular focus on cooperation with Canada, CEPS Special Report, Centre for European Policy Studies, Brussels, September 2008, p. 12.

${ }^{124}$ Francois Crepeau and Delphine Nakache, "Controlling Irregular Migration in Canada: Reconciling Security Concerns with Human Rights Protection”, IRPP Choices, Vol. 12, No. 1, Institute for Research on Public Policy, Montreal, February 2006, p. 5. 


\section{2 | MARINA CAPARINI}

within a polity, is the dominant framework within which efforts have been made to address the severely disadvantaged situation of the Roma in European societies. This was demonstrated during the accession process in the application of a human rights criterion pertaining especially to the Roma, typically one of the most disadvantaged and vulnerable group in many European states, in the political conditions for the candidate states of Eastern Europe. The human rights situation of Roma became a focus of criticism by the European Commission, which spurred various policy initiatives and efforts - although the issue was not deemed sufficiently important to derail the accession of candidate states in which continuing problems had been noted. The denial of the right to state protection of fundamental human rights is the core basis on which the case for Roma asylum claims are being made.

Alongside this inclusive human rights paradigm is the emergence of an exclusionary paradigm comprising the efforts of developed states to reassert sovereign control over migration to their territory. This concern for territorial sovereignty through migration control threatens to erode vital aspects of the international refugee regime and the core obligation of state protection. As doors to refugees and migrants continue to close, finding a means to mediate this tension will be one of the key challenges for liberal, democratic developed states.

\section{Recommendations}

Canada has long held an international reputation for being at the forefront of the promotion of human rights and a popular domestic image of being a multicultural country that welcomes refugees and which is enriched by the diversity of refugees and immigrants. These images risk being eroded by recent policies and developments.

When seeking to correct inefficiencies and abuses of its refugee system, it must do so while still upholding its international obligations for state protection of fundamental rights as a signatory to the international Convention on refugees, as well as upholding the values enshrined in international human rights law and the Canadian Charter of Rights and Freedoms. In that vein, Canada should

- $\quad$ strive to develop and maintain an independent refugee determination process that is insulated from political influence, adequately staffed and resourced;

- $\quad$ ensure that its representatives refrain from prejudging categories of refugees, thereby exerting potential political influence on the IRB and reinforcing negative stereotypes about specific groups of refugee claimants in public perceptions; and

- $\quad$ encourage a more balanced and informed public debate about the refugee system in Canada.

The Czech Republic has introduced numerous measures over the past 13 years to address widespread racism, discrimination, socio-economic marginalisation and acts of violence by state and non-state actors against the Roma. Although some improvements have recently been achieved, such as the passage of comprehensive anti-discrimination legislation, problems with implementation have persisted and these measures have failed to substantially improve the dayto-day situation of the Roma. The Czech Republic should

- $\quad$ ensure that policies for Roma inclusion and anti-discrimination are fully implemented at all levels of public administration, with particular attention to the municipal and local levels;

- $\quad$ ensure full enforcement of the prohibition on hate speech, the dissemination of racism and incitement of racism; 
- $\quad$ ensure that Roma children enjoy equal opportunity to participate in the regular education system and dismantle segregated schooling practices;

- $\quad$ ensure equal treatment before the law by addressing continuing practices of segregation and discrimination in housing, employment, education and access to services, and by ensuring that Roma complaints are duly and impartially investigated and prosecuted by police and state prosecutors;

- $\quad$ tackle discrimination in the judicial system against Roma, specifically by judges who fail to recognise racial motivation for crimes against Roma despite the existence of supporting evidence or who hand down excessively light sentences for such crimes;

- implement additional efforts to transform police organisational culture and police attitudes towards the Roma and other visible minorities through in-service training on anti-discrimination, the recruitment of more members of minority groups and greater attention to the role of police managers; and

- $\quad$ tackle continuing problems of ill treatment and the excessive use of force by police against Roma and police impunity by strengthening police accountability before the law, including through internal disciplinary mechanisms that are more robust, independent and effective mechanisms for civilian complaints, and prosecution before the courts.

The EU has contributed in important ways to raising awareness of Roma exclusion and discrimination. Nevertheless, continuing problems of Roma discrimination and exclusion along with rising intolerance in several member states suggest the need for more coherent action, to

- $\quad$ raise awareness within member states of continuing discrimination and exclusion of Roma within the EU member states and aspiring members;

- $\quad$ share good practices for Roma equality and inclusion among member states, as well as with states aspiring to EU membership;

- develop normative and operational frameworks for democratic policing based on the respect for human rights, accountability and responsiveness to the needs of all members of societies, including marginalised or vulnerable groups; and

- $\quad$ analyse lessons learned in the EU accession process with regard to political conditionality and develop a more robust approach to ensuring that in future enlargements core values such as respect for human rights and minority protection are unambiguously defined, monitored systematically and clearly benchmarked.

- develop normative and operational frameworks for democratic policing based on the respect for human rights, accountability and responsiveness to the needs of all members of societies, including marginalised or vulnerable groups; and

- $\quad$ share good practices for Roma equality and inclusion among member states, as well as with states aspiring to EU membership. 


\section{References}

Alegre, Susie (2008), The EU's External Cooperation in Criminal Justice and Counterterrorism: An assessment of the human rights implications with a particular focus on cooperation with Canada, CEPS Special Report, Centre for European Policy Studies, Brussels, September.

Amnesty International (2009), “Europe's Roma Community Still Facing Massive Discrimination”, Amnesty International, London, 7 April.

(2010a), Amnesty International Report 2010 - Czech Republic, Amnesty International, London.

(2010b), Injustice Renamed: Discrimination in Education of Roma Persists in the Czech Republic, EUR 71/003/2009, Amnesty International, London, January.

Amnesty International, Canadian Council for Refugees, Refugee Lawyers' Association of Ontario (2010), “Bill C-31 Needs Thorough Review”, Joint Public Statement, 27 April.

Bayley, David H. (2006), Changing the Guard: Developing Democratic Police Abroad, Oxford: Oxford University Press.

Bratinka, Pavel (2007), Report on the Situation of the Romani Community in the Czech Republic and Governmental Measures Assisting its Integration into Society, Prague, 29 October.

Camyar, Isa (2010), "Europeanization, Domestic Legacies and Administrative Reforms in Central and Eastern Europe: A Comparative Analysis of Hungary and the Czech Republic”, Journal of European Integration, Vol. 32, No. 2.

Council of Europe, Advisory Committee on the Framework Convention for the Protection of National Minorities (2001), Opinion on the Czech Republic, adopted 6 April 2001, ACFC/INF/OP/I(2002)02, Strasbourg.

(2005), Second Opinion on the Czech Republic, adopted 24 February 2005, ACFC/INF/OP/II(2005)02, Strasbourg.

Crepeau, Francois and Delphine Nakache (2006), "Controlling Irregular Migration in Canada: Reconciling Security Concerns with Human Rights Protection”, IRPP Choices, Vol. 12, No. 1, Institute for Research on Public Policy, Montreal, February.

Czech Republic (2000), Concept of Governmental Policy Towards Members of the Roma Community Supporting their Integration into Society, adopted 14 June, Prague.

Czech Republic Ministry of Interior (2002), National Strategy on Policing Minorities, Prague.

(2008), Information on the Issue of Extremism in the Czech Republic in 2007, Prague.

(2009), Strategy for Combating Extremism - Year 2009, Prague, (http://www.mvcr.cz/mvcren/article/documents-on-the-fight-against-extremism.aspx).

Dauvergne, Catherine (2008), Making People Illegal: What Globalization Means for Migration and Law, Cambridge: Cambridge University Press.

European Commission (1997), Agenda 2000 - Commission Opinion on the Czech Republic's Application for Membership of the European Union, DOC/97/17, Brussels, 15 July.

(2001), 2001 Regular Report on the Czech Republic's Progress Towards Accession, SEC (2001) 1746, Brussels, 13 November. 
(2002), Regular Report 2002, SEC(2002) 1402, Brussels.

(2003), Comprehensive Monitoring Report on the Czech Republic's Preparations for Membership 2003, Brussels.

European Commission against Racism and Intolerance (ECRI) (2000), Second Report on the Czech Republic, adopted 18 June 1999, ECRI, Brussels.

(2009), Report on the Czech Republic, adopted 2 April 2009, ECRI, Brussels.

European Union Agency for Fundamental Rights (FRA) (2009a), EU-MIDIS: European Union Minorities and Discrimination Survey - Main Results Report, Conference edition, FRA, Vienna.

(2009b), Housing discrimination against Roma in selected EU Member States: An analysis of EU-MIDIS data, Conference edition, FRA, Vienna, October.

European Roma Rights Centre (ERRC) (2009), "Roma Rights 1, 2009, Hard Times for Roma: Economics, Politics and Violence”, ERRC, Budapest, 30 July.

Fawn, Rick (2001), “Czech Attitudes Towards the Roma: 'Expecting more of Havel's country?’”, Europe-Asia Studies, Vol. 53, No. 8, p. 1193.

Freedom House (2010), Freedom in the World 2010 - Czech Republic, Freedom House, Washington, D.C.

Guterres, Antonio (2009), "World Refugee Day: 42 million uprooted people waiting to go home”, United Nations High Commissioner for Refugees, Geneva, 19 June.

Human Rights First (2008), 2008 Hate Crime Survey: Roma and Sinti, Human Rights First, New York, NY.

Human Rights Watch (1996), Roma in the Czech Republic: Foreigners in their Own Land, Vol. 8, No. 11 (D), Human Rights Watch, New York, NY, June.

Immigration and Refugee Board (IRB) of Canada (2002), Consolidated Grounds in the Immigration and Refugee Protection Act, IRB, Ottawa, 15 May.

(2009), Issue Paper, Czech Republic: Fact-Finding Mission Report on State Protection, IRB, Ottawa, June.

International Federation for Human Rights (FIDH) and the League of Human Rights in the Czech Republic (LLP) (2002), Czech Republic: Impunity of Racially Motivated Attacks and Police Violence Still Prevails, FIDH and LLP, Paris and Prague, 18 November (http://www.fidh.org/IMG/pdf/cz1811a.pdf).

Kelley, Ninette (2007), "International Refugee Protection Challenges and Opportunities", International Journal of Refugee Law, Vol. 19, No. 3.

Kernerman, Gerald (2008), "Refugee Interdiction Before Heaven's Gate”, Government \& Opposition, Vol. 43, No. 2.

Köhler, Nicholas (2009), “A crackdown on queue-jumpers”, Maclean’s, Vol. 122, Nos. 29/30, 3 August.

Lee, Ronald (2000), "Post-Communism Romani Migration to Canada”, Cambridge Review of International Affairs, Vol. XIII, No. 2.

Lefebvre, Stephane (2003), "Recent research: Roma and the Czech-Canadian visa issue, 19989”, Contemporary Politics, Vol. 9, No. 3, September. 
Macklin, Audrey (2009a), “Asylum and the Rule of Law in Canada: Hearing the Other (Side)”, in Susan Kneebone (ed.), Refugees, Asylum Seekers and the Rule of Law: Comparative Perspectives, Cambridge: Cambridge University Press.

(2009b), "Refugee Roulette in the Canadian Casino", in Jaya Ramji-Nogales, Andrew I. Schoenholtz and Philip G. Schrag (eds), Refugee Roulette: Disparities in Asylum Adjudication and Proposal for Reform, New York and London: New York University Press, pp. 135-163.

O’Nions, Helen (2007), Minority Rights Protection in International Law: The Roma of Europe Aldershot: Ashgate.

Open Society Institute (OSI) (2002), Minority Protection in the Czech Republic, OSI.

Organisation for Security and Cooperation in Europe (OSCE) (2000), Report on the situation of Roma and Sinti in the OSCE area, OSCE, Vienna.

OSCE Office for Democratic Institutions and Human Rights (ODIHR) (2009), Hate Crimes in the OSCE Region - Incidents and Responses: Annual Report for 2008, ODIHR, Warsaw, November

Price, Matthew E. (2009), Rethinking Asylum: History, Purpose, and Limits, Cambridge: Cambridge University Press.

Ram, Melanie H. (2003), "Democratization through European Integration: The Case of Minority Rights in the Czech Republic and Romania”, Studies in Comparative and International Development, Vol. 38, No. 2, Summer.

Shepherd, H.E. (2000), Czechoslovakia: The Velvet Revolution and Beyond, Houndmills, Basingstoke and New York: Palgrave.

Showler, Peter (2007), "Submission to the Standing Committee on Citizenship and Immigration”, 29 March (http://www.ccrweb.ca/documents/showler07.pdf).

Sobotka, Eva (2009), “Czech Republic: Exceptionality and conditionality at work”, in Bernd Rechel (ed.), Minority Rights in Central and Eastern Europe, London and New York: Routledge.

Struharova, Beata (2004), "Disparate impact: Removing Roma from the Czech Republic”, $\begin{array}{llllll}\text { European Roma Rights } & \text { Centre, Budapest, } & 7 & \text { July }\end{array}$ (http://www.errc.org/cikk.php?cikk=549).

Swimelar, Safia (2008), "The Making of Minority Rights Norms in the Context of EU Enlargement: The Czech Republic and the Roma”, International Journal of Human Rights, Vol. 12, No. 4.

US Committee for Refugees and Immigrants (USCRI) (2009), World Refugee Survey 2009, USCRI, Arlington, VA.

US Department of State (2010), 2009 Country Reports on Human Rights Practices - Czech Republic, Washington, D.C., 11 March.

Vermeersch, Peter (2003), "EU Enlargement and Minority Rights Policies in Central Europe: Explaining Policy Shifts in the Czech Republic, Hungary and Poland”, Journal on Ethnopolitics and Minority Issues in Europe, No. 1. 


\section{About CE
Programme Structure}

Founded in Brussels in 1983, the Centre for European Policy Studies (CEPS) is among the most experienced and authoritative think tanks operating in the European Union today. CEPS serves as an leading forum for debate on EU affairs, but its most distinguishing feature lies in its strong in-house research capacity, complemented by an extensive network of partner institutes throughout the world.

\section{Goals}

- To carry out state-of-the-art policy research leading to solutions to the challenges facing Europe today.

- To achieve high standards of academic excellence and maintain unqualified independence.

- To act as a forum for discussion among stakeholders in the European policy process

- To provide a regular flow of authoritative publications offering policy analysis and recommendations.

- To build collaborative networks of researchers, policy-makers and business representatives across the whole of Europe.

- To disseminate our findings and views through our publications and public events.

\section{Assets}

- Multidisciplinary, multinational \& multicultural research team.

- Complete independence to set its own research priorities and freedom from any outside influence.

- Seven research networks, comprising numerous other highly reputable institutes, to complement and consolidate CEPS' research expertise and to extend its outreach.

- An extensive membership base of Corporate and Institutional Members, which provide expertise and practical experience and act as a sounding board for CEPS policy proposals.

\section{Research Programmes}

- $\quad$ Economic \& Social Welfare Policies

- $\quad$ Financial Markets \& Institutions

- $\quad$ Energy \& Climate Change

- Regulatory Policy

- $\quad$ EU Foreign, Security \& Neighbourhood Policy

- $\quad$ Justice \& Home Affairs

- $\quad$ Politics \& Institutions

- $\quad$ Agricultural \& Rural Policy

\section{Research Networks}

- $\quad$ European Capital Markets Institute (ECMI)

- $\quad$ European Climate Platform (ECP)

- $\quad$ European Credit Research Institute (ECRI)

- $\quad$ European Network for Better Regulation (ENBR)

- $\quad$ European Network of Economic Policy Research Institutes (ENEPRI)

- $\quad$ European Policy Institutes Network (EPIN)

- $\quad$ European Security Forum (ESF)

CEPS organises a variety of activities, involving its members and other stakeholders in the European policy debate, including national and EU-level policy-makers, academics, corporate executives, NGOs and the media. Its funding is obtained from a variety of sources, including membership fees, project research, foundation grants, conferences fees, publication sales and an annual grant from the European Commission.
E-mail: info@ceps.eu

Website: www.ceps.eu 